\title{
漁業情報のための衛星画像の等温線解析
}

\author{
小長谷庸夫, 内田 誠, 藤 田弘一 \\ (1987 年 6 月 29 日受理)
}

\section{Contouring of Satellite Images for Fishing Information}

\author{
Tuneo Konagaya, ${ }^{* 1}$ Makoto Uchida, ${ }^{* 1}$ and Koichi Fujita*2
}

\begin{abstract}
This paper deals with the surface temperature mapping of fishing grounds by the use of satellite data. A wide range of subjects of the fishing information in Kumano-Nada sea were discussed using the questionnaires from fishermen and records of satellite images received by Fisheries Research Institute of Mie. Temperature mapping of fishing grounds was carried out by the use of a computer. Results are summarized as follows;

Satellite images of temperature profiles of fishing grounds have become to be widely used by coastal fishermen of Kumano-Nada sea. In the future, it is proposed that communication methods be inproved in order to give out the information more quickly.

Monthly receiving rate of available satellite images was significant for mean value of monthly cloudiness at Kumano-Nada sea; the number of available images received in the sea was 5 in 80 orbits $(6.25 \%)$ in July and 28 in $78(35.89 \%)$ in December 1987.

Under ordinary conditions of Kumano-Nada sea, computer contouring was successful by the use of data estimated by satellite images. This contouring method is useful for the construction of data-base of hydrographical forecast of the fishing grounds.
\end{abstract}

人工衛星によるリヒートセンシングは広水域の海面を 同時に観測出来る上，徽細な水温分布屯表示さ扎るから 漁業関係者心重視され，その評洒は高い。しかし，気象 条件，特に雲や海霧などの影響を受けやすいから漁場の 環境を常に正確に把握できないららみがある。そこで, 衛星画像の解析には良好な数日の画像を重权合わせて留 や霧の部分を除去する方法がとられている。海海況 情報はこの画像をもとにして水塊满造や漁場の位置を等 温線と各種の記号で表わして速報される。”一般にこ の作業には人手に頼る部分が多いから電算機を導入して 処理の客観性と能率の向上をはかる必要がある。また， 漁沉予報には過去の情報の蓄積が久かせないが得星画像 は通常 10 力月程度で消去されているからデーターへー スの棈築が望まれる。出こここでは，漁海洸情報の処理の 効率化をはかるための基礎研究として現況調查と画像の 解析に等高線ブログラムを応用した結果を報告する。

\section{万法}

漁海況速報 三重県水産技術センターは1985年 9 月
から簿星情報による漁海沉速城を開始し，通算 62 号を 刊行した (1987 年 2 月現在)。速報は主として熊野漂北 部海域の近海カッオ一本釣, 延綶, 定置網, 曳絢、サン マ流網、おょびまき網海業などに利用されている。この 海域の 1983 年度の漁獲高は年間 94,363 トンで, ての5 ち上記の漁業により 29,117 トン, $30.9 \%$ が漁獲されて いる。この㴧獲高は三重県全体の $11.7 \%$ 占めてい る。海海況速報はこの海域の主要漁業に利用されてい るから、さらに充実をはかるために漁業者の要望の意向 調査結果*おおよび漁海沅速報の実績を検討した。

等温線解析 人工葦星に上る海洦の情報量は極めて多 く、船舶による観测では調べ得ない複傩な水温棈造がわ かる。いがし、海面の全域が快晴に恵まれることは稀 である。したがって、衛星画像の利用には需の領城の除 去と海霧拈よびスモッグ層などによる誤差の補正が不可 久である。通常衛星画像の解析は10 日を単位とし, 40〜60 軌道の5ち良好な画像の 2 3 枚を重权合わせて 雲の範囲を除き，寒暖流，潮境，泠䐘水張出部，渦なと の位犆を記号で示す。㙂この解析には熟練者による長

*1 三重大学生物资源学部 (Faculty of Bioresources Mie University, Edobashi, Tsu 514, Japan.)

*2 三重斨水鷹技術センター (Fisheries Institute of Mie, Hamajima-chyo, Shima-gun, Mie Pref. 517-04, Japan.)

*3 1983 年度農林水糜省䟽計

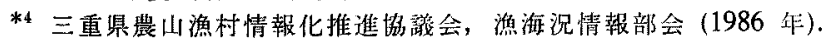




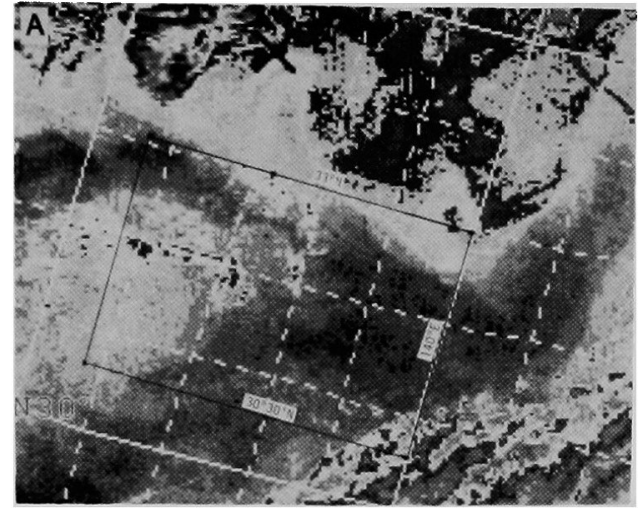

(A)

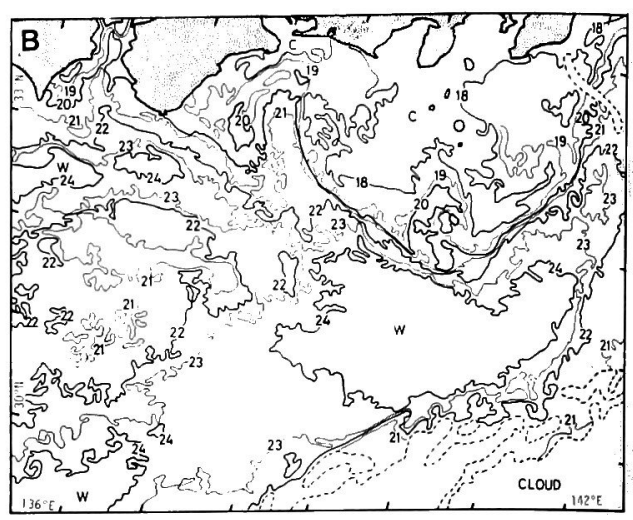

(B)

Fig. 1. Sea-surface temperature proñles off Kumano-Nada sea on May 17, 1986.

(A): Satellite image. (B): Fishing information. (Fishery Research Institute of Mie)

時間の作業が必要であるら光, 個人差も生じやすい。し かし、この作業を一挙に電算化することは困難である。 そこでまず電算機を併用し，段階的に改善を進めてい く必要がある。到ここでは, 地図, 天気図, 水温分布図 なとの作画を目的として開発されたブログラム“CONPAS”*5 の応用を試みた。このプログラムはマトリクス データーで最大 300 点, ランダムデーターで最大 2000 点の 3 次元データーから 3 次元曲面を構成し,この曲面 から等高線や断面線を計算する。曲面解析法にはパラメ トリック構成法を採用し，作画処理は自動化されてい る。解析手法は標準化され, データーの重みづけやノイ ズの除去など経験や勘に頼る要素がない。測点数が少な いばあいや測点の集中や偏在があると不完全なこともあ りらるが手作業と同様な作画性能を目標としている。

まず, 三重県水産技術センターで 1986 年度中に受像 した衛星画像*8 の内, 最も良好な 5 月 17 日の画像を選 んで等温線解析した。この衛星画像の海面部分 $(\mathrm{A})$ とこ
れから手作業によって転写した海況図（B)を Fig. 1 に 示す。漁海況速報はこの転写図に黒潮の流路や漁場位置 を記入したものである。“CONPAS”による解析は図中 の陸岸と雲の影響のない熊里灘沖合の 海域 $\left(30^{\circ} 30^{\prime} \mathrm{N} \sim\right.$ $\left.33^{\circ} \mathrm{N}, 135^{\circ} 30^{\prime} \mathrm{E} \sim 140^{\circ} \mathrm{E}\right)$ に限った。

次に三重大学練習船樊水丸が気象条件の不良な期間に 受像した画像*7を重权合わせて作画し検討した。その方 法は能野灘北部海域の等間隔の定点毎の 10 日間の水温 変化から表面水温を推定して等温線図を作画し，この期 間の直前の比較的良好な画像と比較した。

\section{結果と検 討}

漁海況速報 熊野灘北部海域の沿岸漁業者から寄せら れたアンケート (Table 1) によると衛星情報を操業に利 用している者は $62.5 \%$ であった。回答者は沿岸および 近海のカッオ一本验漁業者が多く, これらの漁業者の期 待の大きさがらかがわれる。また情報の入手に無線フっ

Table 1. Outcome of questionnaires of fishing information from coastal fishermen of KumanoNada

\begin{tabular}{c|c}
\hline \multicolumn{3}{c}{ Satellite information } & $\begin{array}{c}\text { Desires of acquisition } \\
\text { (plural answers) }\end{array}$ \\
\hline Use: $43-$ Useful: 40 \\
$(67.2 \%)$ \\
No use: 20 \\
$(31.3 \%)$ \\
Others: 1 \\
$(1.5 \%)$
\end{tabular}$\quad \begin{gathered}\text { Wireless facsimile: } 28 \\
(29.8 \%) \\
\text { Notice* } \\
(25.5 \%) \\
\text { Useless: } 11 \\
(2.3 \%) \\
(11.7 \%)\end{gathered}$

\footnotetext{
* At the fishermen's cooperative association.
}

*5 CPNPAS (CONtouring Program Aided Special analysis): FACOM 230 OS II OS II/VS CONPAS 解説 書，第 1 版，富士通，東京，1974，1-331.

*8 人工衛星 NOAA-9 号, 受画装置: JCV-6 型, ATP 信号.

*7 人工衛星 NOAA-9 号のほぼ同一轨道の画像, 受画装置: SU-8 型, ATP 信号. 


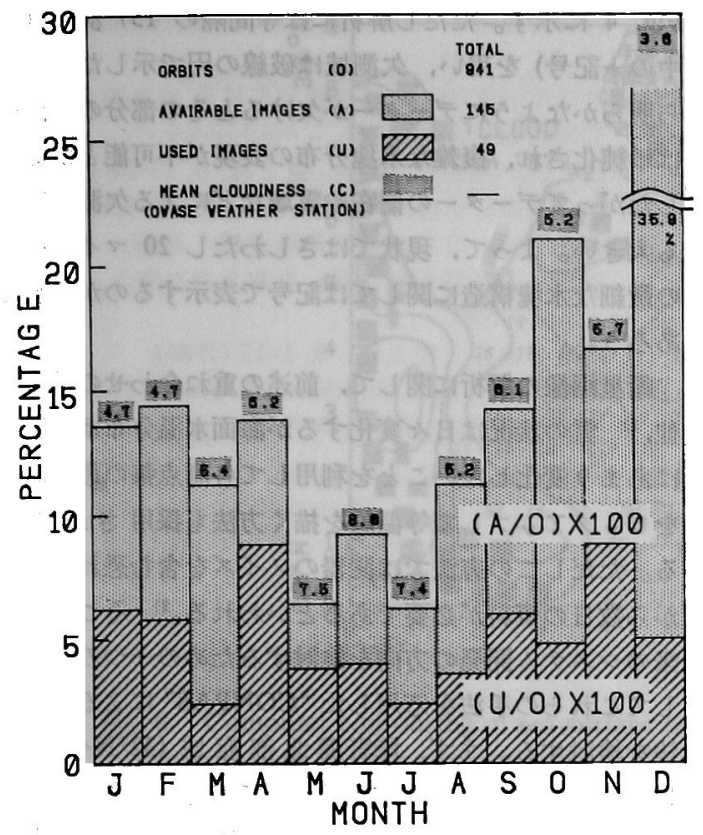

Fig. 2. Monthly records of satellite images received by Fisheries Research Institute of Mie.

ックスの導入を希望する者が特に多からた。この結果は この海域の漁業者か情報の速報性を要望していることを 示す。漁海況速報の内容に関しては水色や漁場位置など の要求が多かった。したがって, きめ細かい情報の解析 る必要である。1986 年度における三重県水産技術センタ 一が受像した NOAA 9 号の衛星画像の記録を Fig. 2 に 示す。困で 1 年間の衛星軌道の総計は 941 回で, その5 ち熊野灘を中心とした海域の天候が良く，解析可能な画 像が得られた軌道は 145 回 (15.4\%) であった。季節毎 の受像記録をみると 5 月と 7 月は約 $6 \%$ であるが, 12 月には約 36\% で初夏から梅雨期にかけて受像率は低く 冬季のそれは高い。尾鴐測候所の観湘結果から月平均雲 量を求めると, 12 月には 3.6 で最低であるが 6 月には 8 と最高となり, 月平均雲量と受像率の間には負の相関 (危険率 5\%) が認められた。一方, 解析可能な海面画像 の得られた軌道数 145 回のらち, 速報に使用した軌道数 は僅か 45 回でこれは全軌道数の 5.2\% にすぎない。 特に 35.9\%の良好な画像が得られた 12 月の解析数と他 の月の相違が認められない。この主な原因は解析者の作 業限界によるるので, 増員, または解析手法の省力化と 効率化を進める必要がある。ただ, 気象条件の悪い初 夏の速報を增加出来ないのは当然である。この季節はこ の海域におけるカッオー本釣, 电縄およびシイラ延縄な どの盛漁期である。よって, 他の方法による観測データ

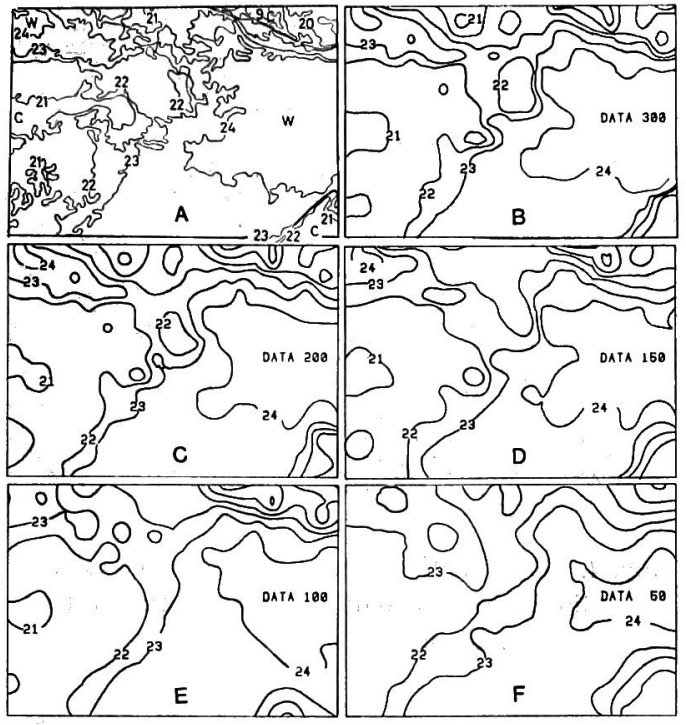

Fig. 3. Contour maps of sea-surface temperature in the Kuroshio-area $\left(30^{\circ} 30^{\prime} \mathrm{N}-33^{\circ} \mathrm{N}\right.$, $\left.135^{\circ} 30^{\prime} \mathrm{E}-140^{\circ} \mathrm{E}\right)$.

(A): Trace of the satellite image. (B-F): Contour maps drawn by a computer with random data of sea-surface temperatures at $300-50$ points.

\section{一も併用する必要がある。}

等温線解析 “CONPAS” の作画性能を検討するため に, 1986 年 5 月 17 日の衛星画像について測点数を様々 に変えて等温線を作画した。その方法は，Fig. 1 に示す 熊野灘北部海域の緯度方向で 150 マイル, 経度方向で 210 マイル間のそれぞれ 15 本および 20 本の等間隔の 格子の各交点を $x y$ 座標で表わし, これと水温との 3 次 元データーを電算機のカードに穿孔した。このカードを トランプの要領で十分切って任意の数を電算機に入力し て等高線プログラム“CONPAS”により等温線を X-Y プロッタで作画した。得られた等温線図の一部および手 作業による転写図を Fig. 3 に示す。図で 350 (B) から 150 測点 (D) による等温線図は転写図のパターン (A) をかなり良く表現する。100 湘点以下でも等温線は微妙 に変化するがその特徵は残る。ここで, 300 測点のぱあ い135 平方マイルあたり 1 測点, 150 測点では 270 平 万マイルあたり 1 測点の割合である (各測点が均等に分 布したと仮定)。一方, 衛星画像の APT (Automatic picture transmission) 信号の分解能は温度で $0.4^{\circ} \mathrm{C}$, 距 離で $4 \mathrm{~km}$ である。*8 したがって転写図は約 4.7 平方マ イルあたり 1 測点のデーターで描かれたことになる。す なわち, “CONPAS” の応用により衛星画像からの直接 の転写の約 $1 / 28$ から $1 / 57$ のデーターでパターンを表現

*8 古野電気株式会社: 気象衛星 NOAA の概要, p 18, 1985. 


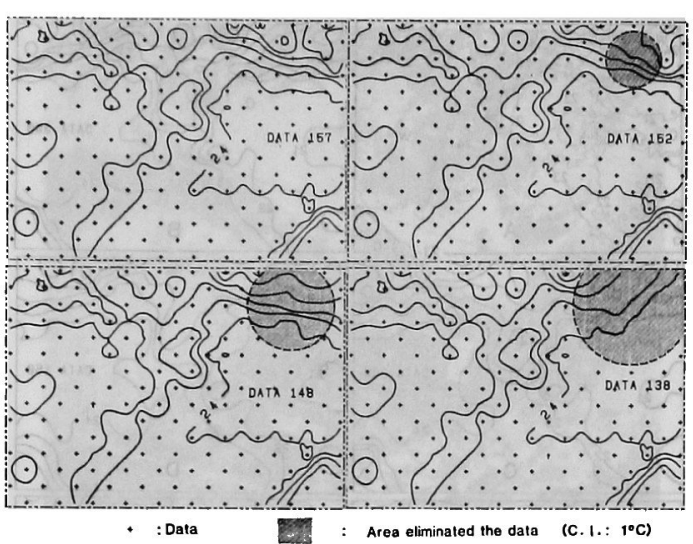

Fig. 4. Deformations of contours due to the elimination of data in dotted circles $(+$ : station measured).

できることになる。しかし、この值は船舶データー $\left(4752 \times 10^{8}\right.$ 平方マイルの海域約 4000 点) に上る漁業情 報サービスセンターの等温線作画例 ${ }^{3)} 1188$ 平方マイル あたり 1 点に比ぺ 4.3 8.6 倍となり熟練者による作画 に比べると測点密度は高い。

熊野漌北部海域では黒潮の流路の変化により暖水舌や 小䁔水塊が現れやすい。吊 また潮境には，冷水と暖水を 巴状に巻き込んだ形状に渦が発生することが多い。 のような複雑な海況を等温線で表現するためにはデータ 一の密度を高めると共に測点の偏在を避ける必要がある と考えられる。そこで上述の海域で等温線の最も複雑な 部分を選んでデーターを次々に除いて作画した結 果を
Fig. 4 に示す。ただし解析には等間隔の 157 湘点 (図 中の十記号) を用い，欠測域は破線の円で示した。図か ら明らかなよらにデーターが久けるとその部分の等温線 は単純化され，複雑な水塊分布の表現が不可能となる。 したがってデーターの偏在や雲域などによる久測の影響 も大きい。よって, 現状ではさしわたし 20 マイル程度 の微細な水塊構造に関しては記号で表示するのが妥当で あろう。

衛星画像の解析に関して, 前述の重站わせの手法の 他, ${ }^{1)}$ 雲の状況は日々变化するが海面水温分布は短期で はあまり変化しないことを利用して各測点毎の最高温度 をピックアップして等温線を描く方法も採用されてい る。ただしこの方法では測器のノイズを含む恐れがある

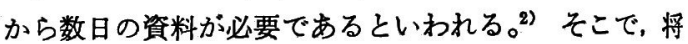
来のシステム開発の方向を検討するための一つの試みと してこれらの手法を応用した “CONPAS” による作画手 法を検討する。まず, 熊野灘北部海域 $\left(32^{\circ} \mathrm{N} \sim 35^{\circ} \mathrm{N}\right.$, $\left.135^{\circ} \mathrm{E} \sim 140^{\circ} \mathrm{E}\right)$ の全域にわたって絶兄ず多数の雲域 で覆われ個々の画像では全く解析が不可能であった期間 (1987 年 1 月 10 日 1 月 19 日) の人工衛星画像を位眉 補正し，陸地部分子含めて緯度方向と経度方向にとれそ れ 10 本と 13 本の格子の各交点 (130 測点) の水温を機 械的に読み取って各測点毎にプロットした (Fig. 5)。困 で各グラフの原点は 130 測点の位置に対応し, それぞれ の $\mathrm{X}$ 軸の長さは 10 日間を, $\mathrm{Y}$ 軸のそれは $0 \sim 20^{\circ} \mathrm{C}$ の 範囲を示す。各グラフをみると、ピーク值は安定しな い。この原因は局部的な晴天域も海霧や水蒸気あるいは 海面の粗度や吹送流の影響を受けるためで, ${ }^{2)}$ リモート

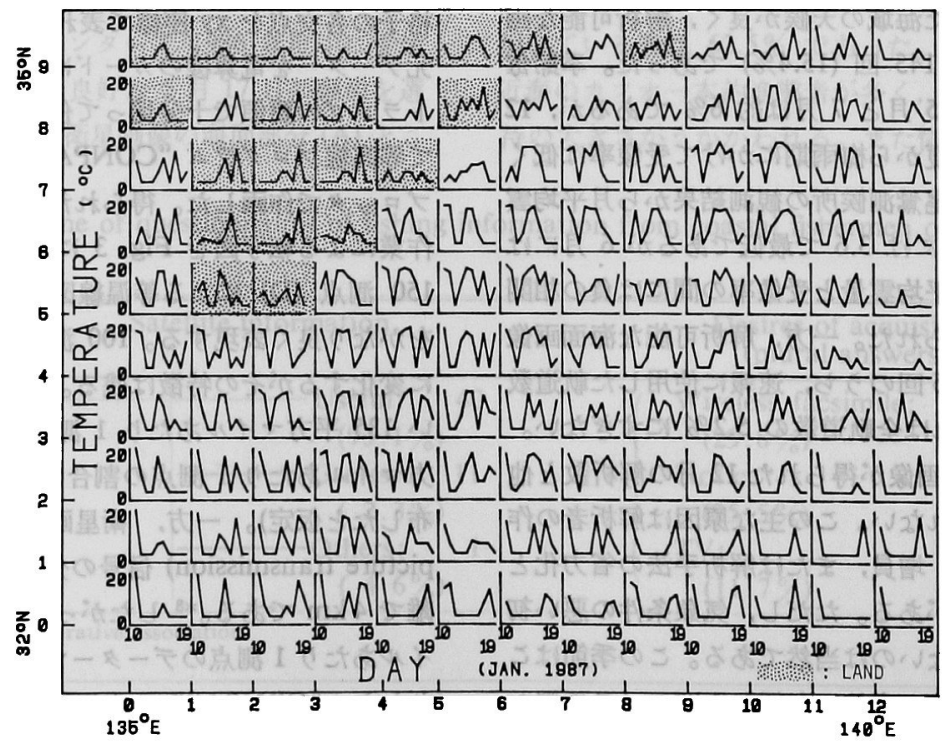

Fig. 5. Daily changes of sea-surface temperatures at 130 points in Kuroshio-area during 10 days of inclement weather (10-19 Jan. 1987). 


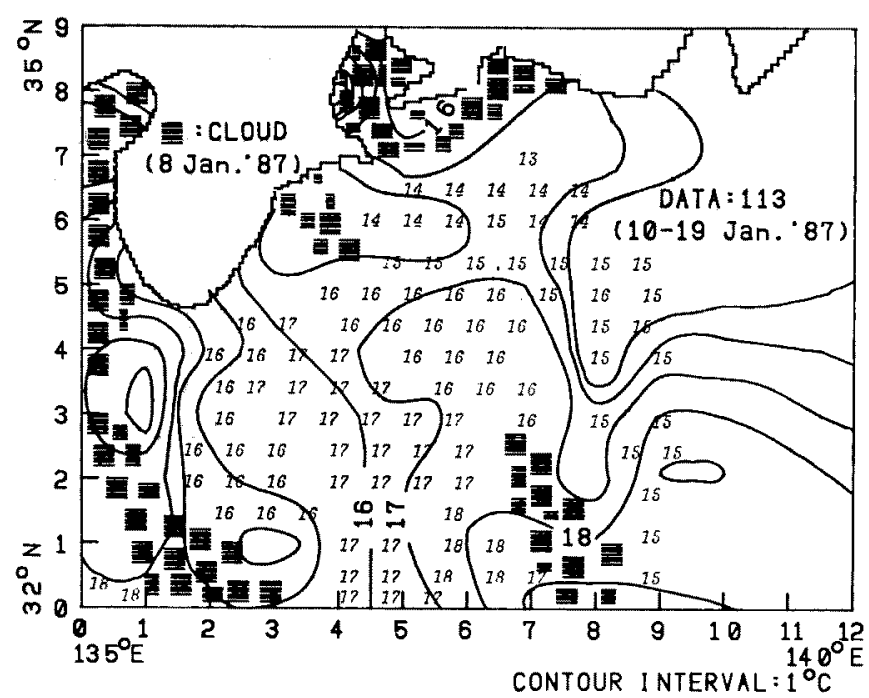

Fig. 6. Computer contouring of sea-surface temperature drawn by the use of maximum temperatures during 10 days at every point in Fig. 5.

Numbers: Sea-surface temperature obtained before the weather breaks (Satellite image on 8 Jan. 1987).

センシングの限界を示す。をた，雲域は最低温度に近 い。いま，各格子の交点の最高水温を海面水温と仮定し て作図した等温線図から陸地部分を除きこれに比較的 良好な海面情報が得られた 1 月 8 日の水塊の水温を数字 で示すと Fig. 6 が得られる。四からみると両者の海水温 の可成りの部分は一致するがパターンは異なる。るっと も，この等温線図はごく一部の海面情報しか得られない 個々の画像から各点の水温を推定して作画した結果であ る。格子状の測点にこだわることなく，晴れ間の部分の 水温を選びランダムデーター (“CONPAS”では 2000

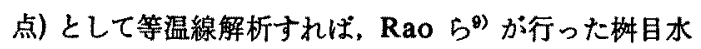
域每の各温度値の出現頻度により測点の重みを增した方 法と同様の効果が期待される。

\section{考察}

本温の絶対値と共に䁔水渦や冷水渦，潮境などの分布 が漁場探索の手掛りとなる。 この観点から広範围の表 面水温分布中微妙な水塊構造が表示される衛星画像利用 の漁海況速報に対する期待は大きい。

現在, 衛星画像の解析は手作業によることが多いが等 高線プログラム“CONPAS”による作画結果は解析の補 助となしえよう。また，19 あるいは $20^{\circ} \mathrm{C}$ の水塊の面積 の大小からカッオの漁獲量を予測する試みがあるが,*B “CONPAS” Kよる作画は客観性が高いからこの種の応 用にも有効であるう。

リモートセンシングは気象条件に左右されやすい。い
わば，雲の間から垣間見た海面情報と言觉る。特に梅雨 期の 6,7 月や台風の多い9,10月の海面の観測はさらに 困難となるから，現状では画像の重ね合わせの手法のみ でなく、船舶などのデーターなどに加え過去の漁況図な どからの判断も必要となる。

現在, 衛星画像は磁気テープに記録されている。しか しこのテープは日々蓄積され，莫大な量となる。また， テープから画像を引き出して再生する方法は時間むかか るし実用的でない。“CONPAS” は海面水温の 3 次元デ ーターから等温線図を作画する。すなわち比較的少ない データーで水温分布をパターン化できる。この3次元の 等温線の作画データーと漁場位置や漁蒦量などのデータ ーベースを構築すれば必要に応じて，過去の㴔海況図を 直ちに㭘索できるから人工衙星応用の漁海況予測法の改 善に役立とう。

この計算は FACOM 230-38S によった。処理能力の 優れた電算機を用いれば熊野灘北部海域の漁場形成と関 連の深い暖水舌や暖冷水塊の微細構造の作画も可能にな る。近く稼動予定の三重大学情報処理教育センターの FACOM M-760/6 によって衛星画像処理のさらに詳細 な研究を進めたい。

\section{謝辞}

本研究には三重大学練習船勢水丸船長, 陣野哲朗氏始 め乗り組又員各位, 並びに三重県水産技術せンター所長 山下悦夫氏はじめ所員の方々の御協力を頂いた。また計 
算には三重大学計算センターの䉓算機 (230-38S) を用 い,オペレーターの伊藤恭子氏の御助言と御助力を頂い た。計算の実行に性三重大学水産学部学生, 浅井吉文氏 の御協力を得た。厚く御礼申し上げる。

此の研究は三重大学教育研究特別経費によった。

$$
\text { 文献 }
$$

1）為石日出生：水産海洋研究会報，45，132-136 (1984).

2) 日本海洋学会：海洋環境調查法，初版，恒星社 恒生閣, 東京, $1979,537 \mathrm{p}$.
3) 為石日出生：日本水産学会漁業愁話会報, 20, 13-24, (1983).

4) 水産庁研究部: 人工衛星利用技術研究關発検剧 会埌告書, 38 (1984).

5) 岡田鋭一, 為石日出生: 空と海, 6, 13-30 (1983).

）青山恒雄：水産海洋研究会報，46，28-29 (1984).

7) 杉本隆成：日本全国沿岸海洋誌，初版，日本海 洋学会沿岸海洋部会編，東海大学出版会，東京， pp. 573-580.

8) 為石日出生：空と海， 8, 1-13 (1986).

9) Rao, P. K., E. L. Smith and R. Koffler: Monthly Weather Rev., 100, 10 (1972). 